\title{
Polyethylene glycol effects on somatic embryogenesis of papaya hybrid UENF/CALIMAN 01 seeds
}

\section{Angelo Schuabb Heringer' ${ }^{1}$ Ellen Moura Vale ${ }^{1}$, Tatiana Barroso', Claudete Santa-Catarina', Vanildo Silveira ${ }^{1 *}$}

'Laboratório de Biotecnologia, Universidade Estadual do Norte Fluminense "Darcy Ribeiro" (UENF),

Campos dos Goytacazes, RJ, Brazil.

2Laboratório de Biologia Celular e Tecidual, Universidade Estadual do Norte Fluminense "Darcy Ribeiro" (UENF), Campos dos

Goytacazes, RJ, Brazil.

*Corresponding author: vanildo@uenf.br

Received: 31 January 2013; Accepted: 15 July 2013

ABSTRACT: Among commercial fruits, papaya (Carica papaya L.) is notably one of the most common ones around the world. The aim of the current study was to establish a somatic embryogenesis protocol for the hybrid UENF/CALIMAN 01, elucidating the effects of sucrose and 2,4-dichlorophenoxyacetic acid (2,4-D) on the induction of embryogenic cultures and the effect of polyethylene glycol (PEG) on somatic embryo maturation. Immature zygotic embryos of $C$. papaya hybrid UENF/CALIMAN 01 were cultured in MS culture medium supplemented with different concentrations of sucrose (30 and $\left.60 \mathrm{~g} \mathrm{~L}^{-1}\right)$ and 2,4-D (0,20, 40 and $\left.80 \mu \mathrm{M}\right)$. The combination of $30 \mathrm{~g} \mathrm{~L}^{-1}$ sucrose and $20 \mu \mathrm{M}$ 2,4-D resulted in the highest induction rates and the largest callus diameters. Furthermore, this combination was associated with the greatest potential to form somatic embryos. To promote maturation, cultures were inoculated in MS medium and exposed to different concentrations of PEG $\left(0,30\right.$ and $\left.60 \mathrm{~g} \mathrm{~L}^{-1}\right)$. The $60 \mathrm{~g} \mathrm{~L}^{-1}$ PEG treatment group had the highest average for the number, maturation and conversion of somatic embryos that resulted in plantlets at the end of the process. The addition of PEG to MS medium led to increased protein synthesis. These results are unprecedented for $C$. papaya hybrid UENF/CALIMAN 01 as the current study demonstrates the development of somatic embryogenesis in this high quality hybrid.

KEYWORDS: Carica papaya L., hybrid, induction, maturation, polyethylene glycol, protein analysis, somatic embryos.

\section{INTRODUCTION}

Papaya (Carica papaya L. - Caricaceae) is an important agricultural crop in tropical and subtropical regions (Chen and Chen 1992). After India, Brazil is the second largest producer of this fruit in the world (FAO 2010). The hybrid UENF/CALIMAN 01 was developed in 2003 by Universidade Estadual do Norte Fluminense Darcy Ribeiro (UENF) together with Caliman Agrícola S.A. UENF/CALIMAN 01 is the first Brazilian hybrid of the Formosa papaya and the Solo group (Ferreguetti 2003). Characteristic advantages of this hybrid over other cultivars in the market include more intensely coloured and firmer pulp, a reddish, sweeter flesh due to increased synthesis and accumulation of soluble solids, and greater uniformity in fruit weight and size, which is typically intermediate. Such characteristics are key factors for exportation (Morais et al. 2007).

Most commercial plantations are established from seedderived plants, resulting in crops with low profitability because of heterogeneity and genetic variation displayed by the plants after cross-pollination (Bhattacharya and Khuspe 2001). 
In addition, this conventional production method leads to increased susceptibility to diseases, and increasing production losses. Biotechnological techniques have been investigated and used as alternatives to conventional seed propagation, including somatic embryogenesis, which represents a potential mean for the successful production of more homogenous plantlets that are free from contaminants and have desirable agricultural characteristics (Schmildt et al. 2007). Thus, somatic embryogenesis may help increase the overall papaya production by cloning elite cultivars that produce high quality fruit.

Many studies on the somatic embryogenesis of C. papaya can be found in literature, allowing significant advances in our understanding of this biotechnological tool being applied for this crop. Bruijne et al. (1974) described one of the first somatic embryogenesis studies, obtaining somatic embryos from petiole segments. Meanwhile, Litz and Conover (1982) induced somatic embryos from ovules inoculated in White's medium supplemented with $20 \%$ coconut milk for several weeks. Chen et al. (1987) obtained somatic embryos from roots inoculated in half-strength MS (Murashige and Skoog 1962) medium supplemented with $5.4 \mu \mathrm{M}$ naphthaleneacetic acid (NAA), $2.3 \mu \mathrm{M}$ kinetin and $2.9 \mu \mathrm{M}$ gibberellic acid (GA ${ }_{3}$ ) for three months. In these pioneer studies, the difficulty to obtain somatic embryos was evident by the low percentage of viable embryogenic cultures and the extensive amount of time required for their induction.

Fitch and Manshardt (1990) established papaya embryogenic cultures from immature zygotic embryos inoculated in MS medium with half the saline concentration, supplemented with $0.45-113.1 \mu \mathrm{M} 2$,4-dichlorophenoxyacetic acid (2,4-D) for three weeks. As a result of this study, the addition of auxin in the culture medium of immature zygotic embryos became commonly used for the induction of somatic embryogenesis of C. papaya (Bhattacharya et al. 2003, Farzana et al. 2008, Ascencio-Cabral et al. 2008, Malabadi et al. 2011, Anandan et al. 2012), including both genitors of the UENF/CALIMAN 01 hybrid, Solo (Malabadi el al. 2011) and Formosa (Almeida et al. 2001). Despite multiple studies on the somatic embryogenesis of C. papaya, an efficient and reproducible regeneration system that can be used with most cultivars is yet to be established (Litz 1986) due to several factors that influence the success of embryogenic cultures, such as initial used explants, culture medium and genotype.

Following the induction of embryogenic cultures, the maturation of somatic embryos is an additional required step. Several agents that promote somatic embryo maturation have been used, such as polyethylene glycol (PEG), which is a high molecular weight polymer that is not permeable to the cell plasma membrane and, therefore, is not metabolised (Stasolla and Yeung 2003). PEG has been used in plant and cell cultures of several species to simulate the effects of water stress (El-Tayeb and Hassanein 2000) or to stimulate maturation and conversion of somatic embryos into plantlets, similar to those that originate from seeds, as observed in Pinus sylvestris (Keinonen-Metta et al. 1996), Abies numidica (Vooková and Kormuták 2002), Panax ginseng (Langhansov et al. 2004), Cryptomeria japonica (Maruyama and Hosoi 2007), Abies cephalonica (Krajnakova et al. 2009), Aesculus hippocastanum (Calic-Dragosavac et al. 2010) and Carica papaya L. (Koehler et al. 2013).

The type of stress caused by PEG is essential to develop the somatic embryo, as it induces the accumulation of storage compounds (Stasolla and Yeung 2003) and the modification of DNA methylation (Smulders and de Klerk 2011), causing an embryo to complete development and proceed to convert into a normal seedling. Storage substances are used to provide nutrients and induce desiccation tolerance during embryo conversion (Coelho and Benedito 2008).

Currently, no studies have been published describing somatic embryogenesis for the hybrid UENF/CALIMAN 01. Studies focused on obtaining and modulating the somatic embryogenesis process of this hybrid will be essential due to the economic importance of this genotype. In this regard, the objectives of the present study were to determine the effects of 2,4-D and sucrose on the initiation of embryogenic cultures, as well as to establish the effect of PEG on changes in protein and maturation of somatic embryos during somatic embryogenesis of the hybrid UENF/CALIMAN 01.

\section{MATERIAL AND METHODS}

Plant material: For the induction of embryogenic cultures of papaya, immature zygotic embryos were isolated from immature papaya seeds of the hybrid UENF/CALIMAN 01 and used as explant. Immature fruits, collected between 120 and $130 \mathrm{~d}$ after anthesis in April 2011, were kindly provided by Caliman Agrícola S/A, located in the city of Linhares (19० $23^{\prime}$ S and $40^{\circ} 4^{\prime} \mathrm{W}$ ) in the State of Espírito Santo, Brazil.

Induction of embryogenic cultures: Immature fruits were disinfected for two minutes in $70 \%$ ethanol and for $30 \mathrm{~min}$ in $50 \%$ commercial bleach, followed by three washes with distilled and autoclaved water. In a laminar flow cabinet, immature seeds were obtained and embryos were isolated to be used as explants. They were then inoculated into test tubes $(25 \times 150 \mathrm{~mm})$ containing $10 \mathrm{~mL}$ of MS medium supplemented with different concentrations of sucrose $\left(30\right.$ and $\left.60 \mathrm{gL}^{-1}\right), 2,4-\mathrm{D}$ $(0,20,40$ and $80 \mu \mathrm{M})$ and Phytage $^{\circledR}\left(2.0 \mathrm{~g} \mathrm{~L}^{-1}\right)$. The $\mathrm{pH}$ of the culture medium was adjusted to 5.8 before Phytage $^{\oplus}$ was 
added. Culture medium was sterilised by autoclaving at $121^{\circ} \mathrm{C}$ for $15 \mathrm{~min}$. After inoculation, test tubes with explants were kept in the dark at $25 \pm 2^{\circ} \mathrm{C}$. Treatments were performed in triplicate, with five test tubes per treatment group. After $30 \mathrm{~d}$ of incubation, the rate of induction (\%) and the diameter ( $\mathrm{mm}$ ) of the induced callus were evaluated.

Maturation of embryogenic cultures: The maturation experiment was conducted using embryogenic cultures obtained during the induction experiment. Three colonies of $200 \mathrm{mg}$ of fresh matter (FM) were inoculated into a Petri dish (90x15 mm) containing $20 \mathrm{~mL}$ of MS culture medium supplemented with myo-inositol $\left(0.05 \mathrm{~g} \mathrm{~L}^{-1}\right)$, Phytagel ${ }^{\odot}\left(2.0 \mathrm{~g} \mathrm{~L}^{-1}\right)$, sucrose $\left(30 \mathrm{~g} \mathrm{~L}^{-1}\right)$ and varying concentrations of PEG MW 3350 (0. 3 and $\left.60 \mathrm{~g} \mathrm{~L}^{-1}\right)$. The $\mathrm{pH}$ of the culture medium was adjusted to 5.8 before Phytagel $^{\circledR}$ was added. The culture medium was sterilised by autoclaving at $121^{\circ} \mathrm{C}$ for $15 \mathrm{~min}$. Cultures were maintained in a growth chamber at $25 \pm 1^{\circ} \mathrm{C}$ in the dark for the first seven $\mathrm{d}$ and, afterwards, in a photoperiod with $16 \mathrm{~h}$ of light $\left(60 \mu \mathrm{mol} \mathrm{m} \mathrm{s}^{-1}\right)$. Four Petri dishes were used per treatment. After $42 \mathrm{~d}$ of cultivation, the percentage of maturation of the induced somatic embryos, increase in callus FM and the number of matured somatic embryos were assessed. Samples containing $300 \mathrm{mg}$ of $\mathrm{FM}$ were stored at $-20^{\circ} \mathrm{C}$ for protein analysis.

Growth analysis: With an initial FM of $200 \mathrm{mg}$ per colony, growth under the different treatment conditions was measured based on increased FM and the final number of somatic embryos. Growth measurements were performed after $42 \mathrm{~d}$ of culture and compared to the initial FM of the colonies. The percentage of maturation and the number of somatic embryos were examined $42 \mathrm{~d}$ after the culture using a light stereomicroscope.

Protein analysis: Protein extracts were prepared in biological triplicates (300 mg FM) for each maturation treatment. Soluble and insoluble proteins were extracted from these cultures according to the method described by Santa-Catarina et al. (2006). Soluble proteins were extracted using a phosphate buffer ( $\mathrm{pH} 7.5$ ) containing $50 \mathrm{mM}$ sodium phosphate dibasic,
$10 \mathrm{mM}$ 2-mercaptoethanol and $1 \mathrm{mM}$ phenylmethylsulfonyl fluoride (PMSF). Supernatants containing the soluble proteins were stored at $-20^{\circ} \mathrm{C}$. Insoluble proteins were extracted from the pellets of soluble protein extraction with Tris- $\mathrm{HCl}$ buffer ( $\mathrm{pH}$ 6.8) containing $65 \mathrm{mM}$ Trizma base, $50 \mathrm{mM}$ PMSF, $2 \%$ sodium dodecyl sulphate (SDS), $10 \%$ glycerol and 320 $\mathrm{mM} \beta$-mercaptoethanol at $100^{\circ} \mathrm{C}$ for five minutes, followed by incubation at $4^{\circ} \mathrm{C}$ for $30 \mathrm{~min}$. After centrifugation at $20,000 \times \mathrm{g}$ for $20 \mathrm{~min}$, supernatants containing the insoluble proteins were stored at $-20^{\circ} \mathrm{C}$. The protein concentration in the supernatant was determined using a PlusOne 2-D Quant kit ${ }^{\oplus}$, with bovine serum albumin as standard.

Data analysis: Results are presented as mean and data were analysed by the ANOVA test $(\mathrm{p}<0.05)$, followed by a SNK test $(\mathrm{p}<0.05)$ (Sokal and Rohlf 1995). Means and standard errors were also used to analyse the data when the ANOVA and SNK tests were not used.

\section{RESULTS}

Induction of embryogenic cultures: The induction of embryogenic cultures of the hybrid UENF/CALIMAN was verified with an immature zygotic embryo as an initial explant. Cultures possessed friable callus that had a clear yellow colour. For the induction of these embryogenic cultures, the addition of sucrose and 2,4-D to culture medium significantly affected the rate of induction (\%) and callus diameter (mm) (Table 1).

The addition of $30 \mathrm{~g} \mathrm{~L}^{-1}$ sucrose resulted in a significantly higher induction rate $(46.7 \%)$ compared to $60 \mathrm{~g} \mathrm{~L}^{-1}(\mathrm{p}<0.05)$, and the resulting embryogenic cultures had an average diameter of $10.6 \mathrm{~mm}$. The concentration of 2,4-D affected the induction rate and diameter of embryogenic cultures, with concentrations of 0,20 and $40 \mu \mathrm{M}$ 2,4-D, producing a significantly higher $(\mathrm{p}<0.05)$ induction rate than $80 \mu \mathrm{M}$ 2,4-D concentrations tested for the hybrid, and the resulting embryogenic cultures had an average diameter of $8.8 \mathrm{~mm}$. Although the induction rate was higher (43.3\%) in the absence of 2,4-D, cultures produced in this medium displayed non-embryogenic characteristics,

Table 1. Rate of induction and diameter of embryogenic cultures of $C$. papaya hybrid UENF/CALIMAN $0142 \mathrm{~d}$ after incubation in the presence of different induction treatments

\begin{tabular}{|c|c|c|c|c|c|c|c|c|c|c|c|c|c|c|}
\hline \multirow{3}{*}{$\begin{array}{l}\text { Dependent } \\
\text { variable }\end{array}$} & \multicolumn{6}{|c|}{ Isolated factor levels } & \multicolumn{8}{|c|}{ Combinations of factor levels (Treatments) } \\
\hline & \multicolumn{4}{|c|}{ 2,4-D ( $\mu \mathrm{M})$} & \multicolumn{2}{|c|}{$\begin{array}{l}\text { Sucrose } \\
\left(\mathrm{g} \mathrm{L}^{-1}\right)\end{array}$} & \multicolumn{8}{|c|}{ 2,4-D $(\mu \mathrm{M})+$ Sucrose $\left(\mathrm{g} \mathrm{L}^{-1}\right)$} \\
\hline & 0 & 20 & 40 & 80 & 30 & 60 & $0-30$ & $20-30$ & $40-30$ & $8-30$ & $0-60$ & $20-60$ & $40-60$ & $8-60$ \\
\hline Induction (\%) & $43.3 a$ & $30.0 a$ & $30.0 a$ & $6.7 \mathrm{~b}$ & $46.7 \mathrm{a}$ & $8.3 b$ & $86.7 a$ & $46.7 \mathrm{~b}$ & $46.7 \mathrm{~b}$ & $6.7 \mathrm{c}$ & $0.0 \mathrm{c}$ & $13.3 c$ & $13.3 c$ & $6.7 \mathrm{c}$ \\
\hline Diameter (mm) & $8.7 a$ & $8.8 a$ & $8.1 \mathrm{a}$ & $3.0 \mathrm{~b}$ & $10.6 a$ & $3.7 \mathrm{~b}$ & 17.4ab & $17.4 \mathrm{ab}$ & $10.2 b$ & $3.3 c$ & $0.0 c$ & $7.3 \mathrm{bc}$ & $4.7 \mathrm{bc}$ & $2.7 \mathrm{c}$ \\
\hline
\end{tabular}

Means followed by the same letter in the same line are not significantly different according to the SNK test $(p<0.05)$. $(n=4)$. 2,4-D - 2,4-dichlorophenoxyacetic acid. 
such as compact callus and translucent white colour (Figure 1A). The MS medium supplemented with $20 \mu \mathrm{M} 2,4-\mathrm{D}$ and $30 \mathrm{~g} \mathrm{~L}^{-1}$ sucrose was selected as the induction medium because it resulted in the optimal induction of embryogenic cultures.
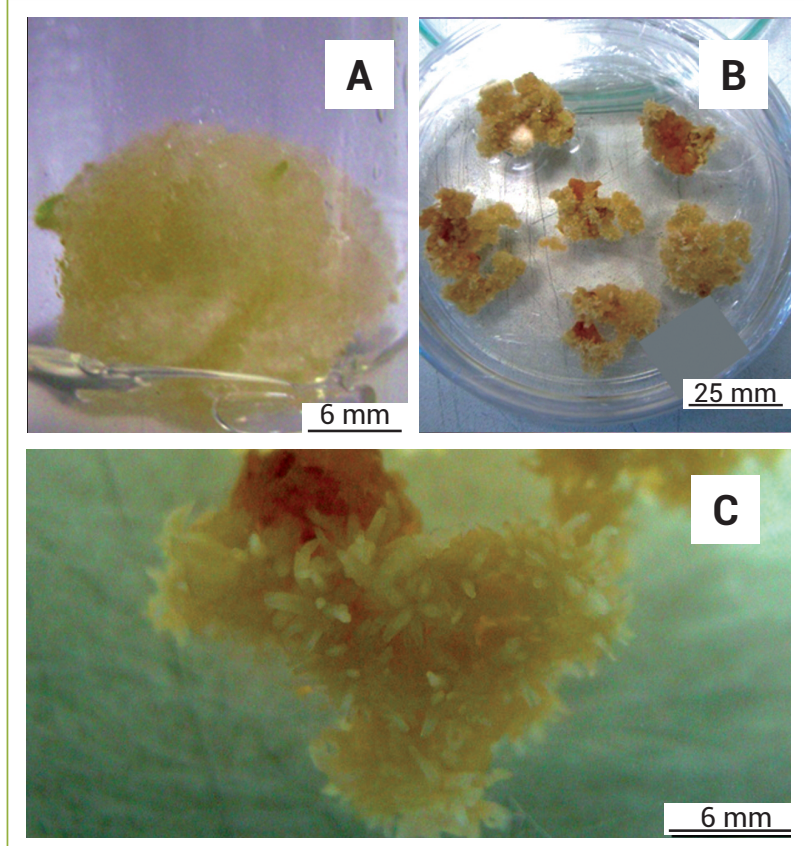

Figure 1. Cultures induced from the zygotic embryo of $C$. papaya hybrid UENF/CALIMAN 01. (A) Non-embryogenic culture obtained from the inoculated explant in MS medium in the absence of 2,4-D. (B and C) Embryogenic cultures obtained from the inoculated explants in test tubes wih MS medium supplemented with $20 \mu \mathrm{M}$ 2,4-D and subcultured in Petri dishes.
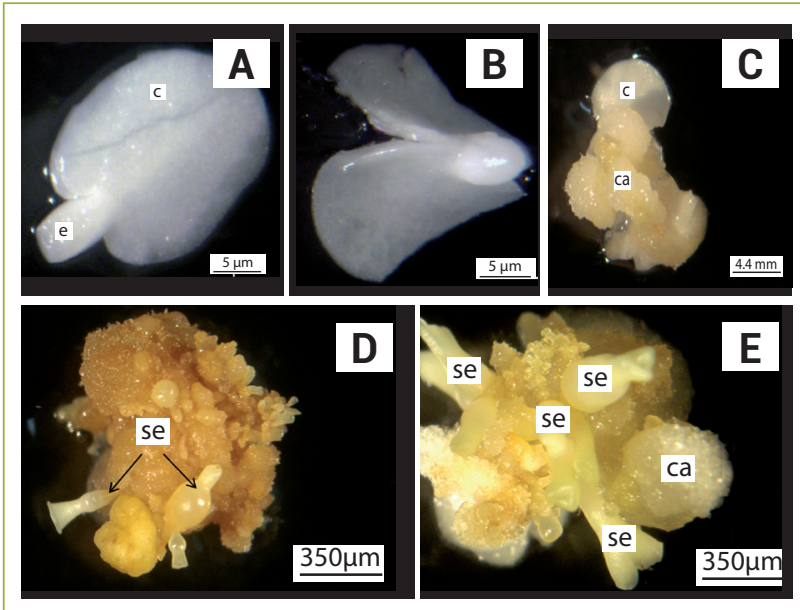

Figure 2. Embryogenic cultures of $C$. papaya hybrid UENF/ CALIMAN 01 inoculated in MS medium supplemented with $20 \mu \mathrm{M} 2,4-D$ and $30 \mathrm{gL}^{-1}$ sucrose. (A) Isolated immature zygotic embryo. (B) Zygotic embryo with open cotyledons (C) Cell culture formation $14 \mathrm{~d}$ after induction. (D and $E$ ) Somatic embryos $25 \mathrm{~d}$ after incubation. se: somatic embryo; c: cotyledon; ca: callus; e: embryonic axis.
The induction of embryogenic cultures (Figure 2A) was assessed daily. The beginning of the induction process was observed on the seventh day of incubation (Figure 2B). Afterwards, a distinct sequence of events could be observed, beginning with the formation of cell cultures from a zygotic embryo in response to auxin and sucrose in the culture medium (Figure 2C). The cultures were kept in the auxin-supplemented medium for $30 \mathrm{~d}$, and the emergence of somatic embryos was observed between the $20^{\text {th }}$ and $25^{\text {th }}$ d of induction (Figures 2D-E).

\section{Maturation and conversion of somatic embryos: The} treatment containing $60 \mathrm{~g} \mathrm{~L}^{-1} \mathrm{PEG}$ resulted in the highest responses of maturation (83.3\%) of the embryogenic cultures (Figures 3A,B). Furthermore, $60 \mathrm{~g} \mathrm{~L}^{-1}$ PEG treatment showed the highest number of somatic embryos, formed in 78 somatic embryos/ callus (Figure 3C). These results show the direct effect of PEG on maturation of the somatic embryos of this hybrid. This treatment facilitated maturation of somatic embryos and their conversion into plantlets similar to those that originate from seed, with the development of leaves and stems occurring $50 \mathrm{~d}$ after incubation (Figure 3D).
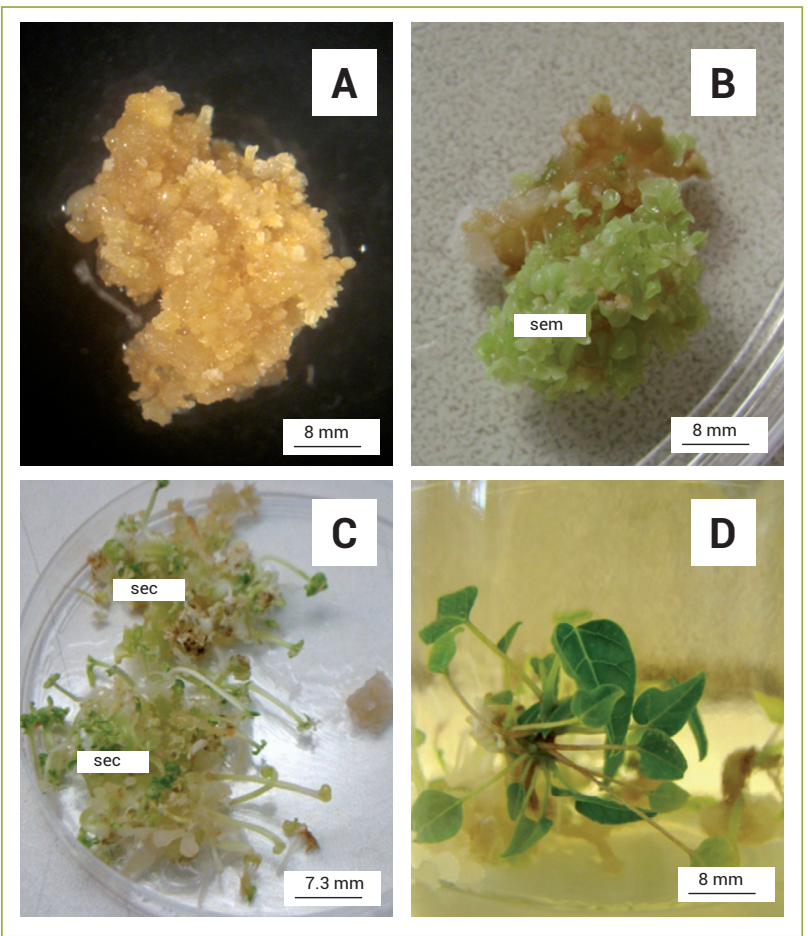

Figure 3. Embryogenic cultures of $C$. papaya hybrid UENF/CALIMAN 01 in MS medium supplemented with $60 \mathrm{gL}^{-1}$ PEG. (A) Embryogenic culture at the beginning of maturation. (B) Embryogenic culture $21 \mathrm{~d}$ after incubation. (C) Matured/converted somatic embryos $42 \mathrm{~d}$ after incubation. (D) Plantlets regenerated from somatic embryos $50 \mathrm{~d}$ after incubation. sem: somatic embryos matured; sec: somatic embryos converted. 
Table 2. Percentage of maturation, increased FM and the number of mature somatic embryos produced in embryogenic cultures of C. papaya hybrid UENF/CALIMAN $0142 \mathrm{~d}$ after incubation under different maturation treatments

\begin{tabular}{lccc}
\multirow{2}{*}{ Variables } & \multicolumn{3}{c}{ PEG $\left(\mathrm{g} \mathrm{L}^{-1}\right)$} \\
\cline { 2 - 4 } Maturation (\%) & $33.3 \mathrm{~b}^{\mathrm{a}}$ & $50.0 \mathrm{ab}$ & $83.3 \mathrm{a}$ \\
\hline FM (g) & $0.23 \mathrm{a}$ & $0.27 \mathrm{a}$ & $0.21 \mathrm{a}$ \\
\hline Number of SE & $52.3 \mathrm{~b}$ & $54.7 \mathrm{~b}$ & $78.8 \mathrm{a}$ \\
\hline
\end{tabular}

aMeans followed by the same letter in the same line are not significantly different according to the SNK test $(p<0.05)$. $(n=4)$. PEG: polyethylene glycol; FM: fresh matter; SE: somatic embryos.

In the control group without PEG, low rates of maturation and progression of somatic embryos were observed (Table 2), and the increase was only observed in the FM of embryogenic cultures.

Protein content: Protein quantification revealed that the soluble fraction was more representative in terms of protein content compared with the insoluble fraction (Figure 4) in embryogenic cultures. On average, extracted soluble proteins contained 4-10 $\mathrm{mg}$ of protein $\mathrm{g}^{-1}$ of $\mathrm{FM}$, whereas insoluble proteins typically had $1.5-2.5 \mathrm{mg}$ of proteins $\mathrm{g}^{-1}$ of FM (Figure 4). The maturation treatment modulated protein content (Figure 4), with a greater concentration of soluble proteins compared to insoluble proteins. The treatment with $60 \mathrm{~g} \mathrm{~L}^{-1}$ PEG induced the increased synthesis of both soluble and insoluble proteins (Figure 4). Additionally, cultures in this treatment group possessed the highest average concentration of soluble proteins at $9.4 \mathrm{mg} \mathrm{g}^{-1}$ of FM (Figure 4).

\section{DISCUSSION}

Induction of embryogenic cultures: In the present study, generated embryogenic cultures formed friable yellow and granular aggregated cells and a lower growth rate compared to non-embryogenic cultures (Figure 1). Similar characteristics were also observed in embryogenic cultures of other species, such as Medicago arborea (Martin et al. 2000), Passiflora cincinnata (Silva et al. 2009) and P. edulis (Pinto et al. 2011), as well as C. papaya cv. Co-7 (Anandan et al. 2012). Conversely, non-embryogenic cultures displayed a different morphological pattern. In the present study, we observed that these cultures had a compact appearance, with translucent white colour and growth rate higher than embryogenic cultures (Figure 1A). Similar features were also observed by Anandan et al. (2012) in the embryogenic cultures of C. papaya cv. Co-7 and by others in M. arborea (Martin et al. 2000) and Daucus carota (Jiménez and Bangerth 2001).

The beginning of the callus induction occurred on the $7^{\text {th }}$ day after the incubation of the explant in the induction culture

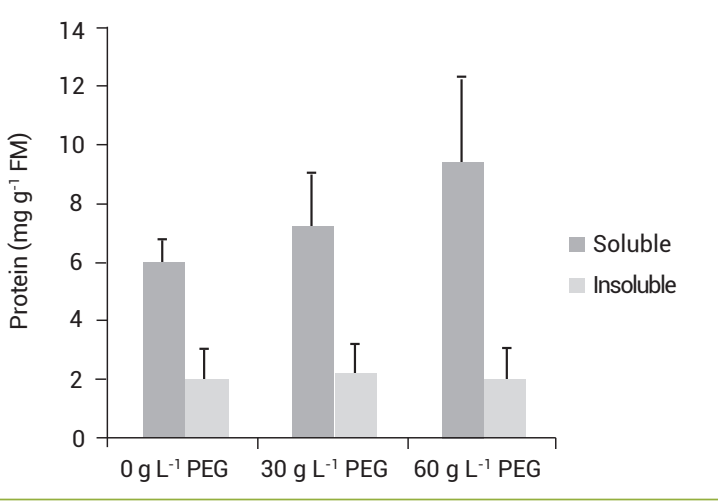

Figure 4. Concentration of soluble and insoluble proteins in embryogenic cultures of $C$. papaya hybrid UENF/CALIMAN 01 subjected to different maturation treatments $\left(0,30,60 \mathrm{~g} \mathrm{~L}^{-1}\right.$ of polyethylene glycol - PEG) (mean \pm standard deviation, $n=4)$.

medium, indicating a rapid response compared to other cultivars that had been previously assessed (Farzana et al. 2008, Malabadi et al. 2011, Anandan et al. 2012). For cv. Rathna (Farzana et al. 2008) and cv. Co-7 (Anandan et al. 2012), callus induction occurred 14 and $10-15 \mathrm{~d}$, respectively, after explant incubation in culture medium. Malabadi et al. (2011), working with twelve cultivars, observed callus induction only $28 \mathrm{~d}$ after of incubation.

In the present study, the formation of somatic embryos from embryogenic cultures occurred between the $20^{\text {th }}$ and the $25^{\text {th }} \mathrm{d}$ of incubation, which was also a rapid response compared to other cultivars. For cv Rathna (Farzana et al. 2008), somatic embryos were observed 10 weeks after incubation in MS medium with 16.1 $\mu \mathrm{M}$ NAA, whereas Malabadi et al. (2011), working with twelve cultivars, observed the somatic embryos eight weeks later in MS medium with $4.52 \mu \mathrm{M}$ 2,4-D or $2.27 \mu \mathrm{M}$ thidiazuron (TDZ). This indicates that the supplementation of the induction medium with $20 \mu \mathrm{M}$ 2,4-D was efficient both for the induction of embryogenic cultures of the hybrid UENF/CALIMAN 01 and the rapid differentiation of somatic embryos.

One possible explanation for this finding is that a synthetic auxin analogue, such as 2,4-D, plays a fundamental role in the induction of embryogenic cultures of papaya due to a variety of effects caused by this growth regulator in the tissue of the explant. In addition to being the main family of growth regulators of plants during division, differentiation and cellular cycle (Fehér et al. 2003), auxins can modulate DNA methylation patterns in cells (Smulders and de Klerk 2011). Specifically, Lo Schiavo et al. (1989) observed that auxins caused epigenetic changes in the DNA of plants by modifying the methylation state, suggesting that the dedifferentiation of differentiated cells allows the appearance of embryogenic cells. 
Recently, Smulders and de Klerk (2011) demonstrated that in vitro cultures are subjected to many forms of stress, such as high doses of auxin, to which the plant tissue expresses various responses, including modification of the DNA methylation pattern, which allows the development of embryogenic cells. In addition, the concentration of phytohormones may determine cellular response, as reported by Anandan et al. (2012), who observed that the formation of embryogenic cultures (friable callus with a clear colour) was affected by the exposure of explants to low $(2.3 \mu \mathrm{M})$ or high $(54.3 \mu \mathrm{M})$ concentrations of $2,4-\mathrm{D}$. At high concentrations, the callus displayed non-embryogenic characteristics (a more spongy, non-friable aspect and dark colouration).

Conversely, the current study found the need to add a relatively high concentration of 2,4-D $(20 \mu \mathrm{M})$ to culture medium in order to induce embryogenic cultures. Although callus induction from explants inoculated into the medium without 2,4-D was 43.3\%, this callus did not display embryogenic characteristics. On the other hand, when explants were inoculated into a medium supplemented with $80 \mu \mathrm{M} 2$,4-D, the induction rate decreased from 43.3 to $6.7 \%$ (Table 1), indicating that the formation of an embryogenic callus in papaya hybrid UENF/CALIMAN 01 depends on an optimal concentration of 2,4-D.

Another factor that significantly affected the induction of embryogenic cultures in papaya hybrid UENF/CALIMAN 01 was the concentration of sucrose in the medium (Table 1). A lower concentration of sucrose $\left(30 \mathrm{~g} \mathrm{~L}^{-1}\right)$ proved to be more efficient in the induction of embryogenic cultures than in higher $\left(60 \mathrm{~g} \mathrm{~L}^{-1}\right)$ concentrations. The results observed for this hybrid are consistent with other papaya cultivars. Malabadi et al. (2011) used $30 \mathrm{~g} \mathrm{~L}^{-1}$ sucrose as standard for the induction of embryogenic cultures of papaya, and verified in 12 cultivars that this concentration yielded the best response. Conversely, Anandan et al. (2012) induced embryogenic cultures with 60 $\mathrm{g} \mathrm{L}^{-1}$ sucrose, followed by a reduction to $30 \mathrm{~g} \mathrm{~L}^{-1}$ in culture medium to induce embryogenic responses and facilitate the development of somatic embryos.

These studies suggest that carbohydrates significantly affect the induction phase of embryogenic cultures in C. papaya. One of these influences is the regulation of the expression of some genes, some of which are enzymes involved in sucrose metabolism, which plays a crucial role in plant development (Koch 2004). These enzymes are responsible for maintaining levels of sucrose and hexose in plant tissue and modulate cellular metabolism. When hexose is predominant, cell division and differentiation are favoured, but when sucrose is predominant, cell elongation and storage of proteins and carbohydrates in tissues are favoured (Borisjuk et al. 2002, Borisjuk et al. 2003).
Sucrose at a concentration of $30 \mathrm{~g} \mathrm{~L}^{-1}$ may have favoured the development of somatic embryos because it induced cellular multiplication and redifferentiation for the formation of somatic embryos, whereas sucrose at a higher concentration (60 $\left.\mathrm{g} \mathrm{L}^{-1}\right)$ may have inhibited this predisposition towards cell division, hindering the formation of somatic embryos. Therefore, future studies should be carried out to quantify the content of endogenous carbohydrates in embryogenic cultures grown in the presence of both sucrose concentrations to clarify the role of these compounds in the induction of embryogenic cultures of C. papaya hybrid UENF/CALIMAN 01.

Carbohydrates are also related to the osmotic environment during somatic embryo maturation, influencing the regulation of gene expression (Businge et al. 2013). However, when sucrose concentration is too high, the osmotic effect of this compound just disturbs callus induction. Sucrose is a permeating osmoticum involving apoplastic invertase in the tissue and extracellular invertase in the medium, a different PEG which is a nonpermeating osmoticum (Wind et al. 2010). These authors emphasized that the manipulation of the rate of synthesis, as well as transportation or degradation of sucrose affect plant growth, development and physiology, which was clearly observed in the present study. Based on results from this sduty and given the importance of the concentrations of sucrose and auxin in the induction medium to obtain embryogenic cultures, the combination of $20 \mu \mathrm{M} 2,4-\mathrm{D}$ and $30 \mathrm{~g} \mathrm{~L}^{-1}$ sucrose was established as an ideal treatment for the induction of embryogenic cultures, resulting in higher rate of induction and larger callus diameter. Therefore, MS medium supplemented with $20 \mu \mathrm{M} 2$, 4-D and $30 \mathrm{~g} \mathrm{~L}^{-1}$ sucrose was determined to be the induction medium for C. papaya hybrid UENF/CALIMAN 01. The relationship between auxin and sucrose for the induction of embryogenic cultures has already been discussed in previous studies, showing that the response of the induction depends on the balance between these two components. Lazzeri et al. (1988), working with Glycine max, demonstrated the significant interaction between concentrations of auxin and sucrose in the medium. The obtained number of somatic embryos was reduced when the auxin/sucrose ratio was higher. These results suggest that the interaction between these two components is essential for the induction of embryogenic cultures from a differentiated tissue.

Maturation of embryogenic cultures: PEG significantly affected somatic embryo maturation of papaya hybrid UENF/ CALIMAN 01 embryogenic cultures. Maturation is a crucial phase in the somatic embryogenesis process, in which the addition of maturation promoters, such as PEG (KeinonenMetta et al. 1996, Vooková and Kormuták 2002, Langhansov et al. 2004, Maruyama and Hosoi 2007, Krajnakova et al. 2009, 
Calic-Dragosavac et al. 2010), abscisic acid (ABA) (Find 1997, Vahdati et al. 2008, Calic-Dragosavac et al. 2010, Anandam et al. 2012), maltose (Li et al. 1998) and activated charcoal (Krajnakova et al. 2009, Calic-Dragosavac et al. 2010), is crucial to promote the maturation of somatic embryos and conversion into plantlets.

PEG does not cause damage in the tissue, which may occur in response to water stress, during which the tissue could experience plasmolysis (Walker and Parrott 2001, Calic-Dragosavac et al. 2010). In the present study, we observed that $60 \mathrm{~g} \mathrm{~L}^{-1}$ PEG induced the highest rates of maturation (83.3\%) of embryogenic cultures and conversion of somatic embryos compared to control, which displayed a 33.3\% maturation rate without PEG supplementation. Langhansov et al. (2004) concluded that somatic embryos of P. ginseng treated with a PEG-supplemented medium achieved greater structural development, which was demonstrated anatomically. These authors also found that plants obtained from somatic embryos treated with PEG displayed better root formation, facilitating subsequent acclimatisation. Recently, Koehler et al. (2013) reported that the addition of $50 \mathrm{~g} \mathrm{~L}^{-1} \mathrm{PEG}$, along with $2 \mathrm{~g} \mathrm{~L}^{-1}$ activated charcoal and $5 \mu \mathrm{M} \mathrm{ABA}$, to papaya somatic embryos led to the improved quality of somatic embryos and the formation of plantlets. These studies suggest that PEG is an inducer of maturation and conversion of somatic embryos.

In addition, the number of mature somatic embryos obtained $42 \mathrm{~d}$ later in culture with $60 \mathrm{~g} \mathrm{~L}^{-1}$ PEG was higher than other treatments, with an average of 78 somatic embryos per callus. Maturation of somatic embryos of papaya hybrid UENF/CALIMAN 01 depends on this high concentration of PEG $\left(60 \mathrm{~g} \mathrm{~L}^{-1}\right)$. Furthermore, PEG is rarely used in the maturation of somatic papaya embryos. As such, the present study is a pioneer in the field. Mishra et al. (2010), demonstrated that the supplementation of conversion medium with PEG ( $\left.45 \mathrm{~g} \mathrm{~L}^{-1}\right)$ led to a synchronised maturation process of transformed embryos.

Therefore, maturation/conversion of somatic embryos is dependent on stress that allows embryonic development to progress. As with induction, maturation of somatic embryos also appears to be highly dependent on stress. This stress modifies the DNA methylation pattern (Smulders et al. 2011) and causes the expression of proteins, which is essential to develop somatic embryos, enabling these embryos to correctly mature. Conversely, for some cultivars of papaya, the addition of other maturation promoters, such as ABA, is necessary. Anandam et al. (2012), working with embryogenic cultures of papaya cv Co-7, showed that $39.7 \mu \mathrm{M} \mathrm{ABA}$ increased the number of mature somatic embryos compared to other treatments.
In the present study, PEG induced increased protein content (Figure 4). This increase in PEG-induced proteins may be related to the synthesis of Late Embryogenesis Abundant (LEA) proteins. The expression of these proteins is associated with the acquisition of tolerance to the desiccation of seeds, and some LEA proteins are induced by cold or osmotic stress (Welin et al. 1994). Their exact function is still unknown, but studies have shown that they are related to the protection of cellular or molecular structures from damage, which may result from water loss during the desiccation of the seed (Goyal et al. 2005). Aroucha et al. (2005), working with papaya seeds of the Golden and Taining 01 cultivars, found that recently collected seeds, regardless of the state of maturation of the fruits, displayed low initial germination, making the storage period necessary for seed germination.

These stored seeds then had a germination rate higher than $80 \%$, which could be related to the desiccation of the seed. Comparing somatic embryos to zygotic embryos, both need this water stress during the desiccation phase to induce germination/conversion of the embryos. This outcome may be related to the synthesis of LEA proteins during this period.

Finally, in the present study, the optimal induction medium for embryogenic cultures was determined to be MS supplemented with $20 \mu \mathrm{M}$ 2,4-D. The addition of $60 \mathrm{~g}$ $\mathrm{L}^{-1}$ PEG is essential for the maturation and the conversion of somatic embryos of hybrid UENF/CALIMAN 01. Therefore, plantlets of somatic origin are an alternative to seedling propagation. The data herein are unprecedented for the hybrid UENF/CALIMAN 01, and this study represents the first examination of somatic embryogenesis performed for this hybrid.

The present study elucidated aspects of somatic embryogenesis of C. papaya, enabling the design of a feasible protocol for somatic embryogenesis that can be used in mass production of plantlets in commercial scale. The method described herein generates more homogenous papaya plantlets from the hybrid UENF/CALIMAN 01.

\section{ACKNOWLEDGMENTS}

We thank the Carlos Chagas Filho Foundation for Research Support in the State of Rio de Janeiro (FAPERJ), Coordination for Enhancement of Higher Education Personnel (CAPES) and the National Council for Scientific and Technological Development (CNPq) for their financial support. The authors also thank Caliman Agrícola S.A. for kindly providing the fruits. 


\section{REFERENCES}

Ascencio-Cabral A, Rodríguez-Garay B, Gutiérrez-Pulido $\mathrm{H}$, Gutiérrez-Mora A (2008) Plant regeneration of Carica papaya through somatic embryogenesis in response to light quality, gelling agent and phloridzin. Scientia Horticulturae 118:155-160.

Anandan R, Sudhakar D, Balasubramanian P, Gutieirrez-Mora A (2012) In vitro somatic embryogenesis from suspension cultures of Carica papaya L. Scientia Horticulturae 136:43-49.

Aroucha EMM, Silva RF, Oliveira JG, Viana AP, Gonzaga MP (2005) Época de colheita e período de repouso dos frutos de mamão (Carica papaya L.) cv Golden na qualidade fisiológica das sementes. Ciência Rural 35:537-543.

Bhattacharya J, Khuspe SS (2001) In vitro and in vivo germination of papaya (Carica papaya L.) seeds. Scientia Horticulturae 91:39-49.

Bhattacharya J, Renukdas NN, Khuspe SS, Rawal SK (2003) Multiple shoot regeneration from immature embryo explants of papaya. Biologia Plantarum 47:327-331.

Borisjuk L, Walenta S, Rolletschek H, Mueller-Klieser W, Wobus $\mathrm{U}$, Weber H (2002) Spatial analysis of plant metabolism: Sucrose imaging with Vicia faba cotyledons reveals specific development patterns. The Plant Journal 29:521-530.

Borisjuk L, Rolletschek H, Wobus U, Weber H (2003) Differentiation of legume cotyledon as related to metabolism gradients and assimilate transport into seeds. Journal of Experimental Botany 54:503-512.

Bruijne E de, Langhe E de, Van Rijck R (1974) Actions of hormones and embryoid formation in callus cultures of Carica papaya. In International Symposium on Crop Protection, Fytofarmacie en Fytiatrie Rijkslandsbouwhoogeschool Medelelingen 26:637-645.

Businge E, Bygdell J, Wingsle G, Moritz T, Egertsdotter U (2013) The effect of carbohydrates and osmoticum on storage reserve accumulation and germination of Norway spruce somatic embryos. Physiologia Plantarum doi:10.1111/ppl.12039.

Calic-Dragosavac D, Zdravkovi-Kora S, Bohanec B, Radojevi L, Vinterhalter B, Stevovi S, Cingel A, Savi J (2010) Effect of activated charcoal, abscisic acid and polyethylene glycol on maturation, germination and conversion of Aesculus hippocastanum androgenic embryos. African Journal of Biotechnology 9:3786-3793.

Chen MH, Wang PJ, Maeda E (1987) Somatic embryogenesis and plant regeneration in Carica papaya L. tissue culture derived from root explants. Plant Cell Reports 6:348-351.

Chen MH, Chen CC (1992). Plant regeneration from Carica protoplasts. Plant Cell Reports 11:404-407.

Coelho CMM, Benedito VA (2008) Seed development and reserve compound accumulation in common bean (Phaseolus vulgaris L.). Seed Science and Biotechnology 2:42-52.

Almeida PA, Oliveira RP, Dantas JLL (2001) Papaya callus and somatic embryo induction and development. Scientia Agricola 58: $51-54$.
El-Tayeb MA, Hassanein AM (2000) Germination, seedling growth, some organic solutes and peroxidase expression of different Vicia faba lines as influenced by water stress. Acta Agronomica Hungarica 48:11-20.

FAO (Food and Agriculture Organization of the United Nations)/ FAOSTAT, 2010. http://faostat.fao.org/site/339/ default.aspx

Farzana ARF, Palkadapala PGVN, Meddegoda KMMN, Samarajeewa PK, Eeswara JP (2008) Somatic embryogenesis in papaya (Carica papaya L. cv. Rathna). Journal of the National Science Foundation of Sri Lanka 36:41-50.

Fehér A, Pasternak TP, Dudits D (2003) Transition of somatic plant cells to an embryogenic state. Plant Cell, Tissue and Organ Culture 74:201-228.

Ferreguetti GA (2003) Caliman 01 - 0 primeiro híbrido mamão Formosa brasileiro. In: Annals of the Papaya Brasil, Vitoria. pp. 211-218.

Find $\mathrm{JI}$ (1997) Changes in endogenous ABA levels in developing somatic embryos of Norway spruce (Picea abies (L.) Karst.) in relation to maturation medium, desiccation and germination. Plant Science 128:75-83.

Fitch M, Manshardt R (1990) Somatic embryogenesis and plant regeneration from immature zygotic embryos of papaya (Carica papaya L.). Plant Cell Reports 9:320-324.

Goyal K, Walton LJ, Tunnacliffe A (2005) LEA proteins prevent protein aggregation due to water stress. Biochemical Journal 388:151-157.

Jiménez VM, Bangerth F (2001) Endogenous hormone levels in explants and in embryogenic and non-embryogenic cultures of carrot. Physiologia Plantarum 111:389-395.

Keinonen-Metta La K, Jalonen P, Eurola P, Von Arnold S, Von Weissenberg K (1996) Somatic embryogenesis of Pinus sylvestris. Scandinavian Journal of Forest Research 11:242-250.

Koch KE (2004) Sucrose metabolism: regulatory mechanism and pivotal roles in sugar sensing and plant development. Current Opinion in Plant Biology 7:235-246.

Koehler AD, Carvalho CR, Abreu IS, Clarindo WR (2013) Somatic embryogenesis from leaf explants of hermaphrodite Carica papaya: A new approach for clonal propagation. African Journal of Biotechnology 12:2386-2391.

Krajnakova J, Haggman H, Gomory D (2009) Effect of sucrose concentration, polyethylene glycol and activated charcoal on maturation and regeneration of Abies cephalonica somatic embryos. Plant Cell, Tissue and Organ Culture 96:251-262.

Langhansov L, Konrdov H, Vanek T (2004) Polyethylene glycol and abscisic acid improve maturation and regeneration of Panax ginseng somatic embryos. Plant Cell Reports 22:725-730. 
Lazzeri PA, Hildebrand DF, Sunega J, Williams EG, Collins GB (1988) Soybean somatic embryogenesis: interactions between sucrose and auxin. Plant Cell Reports 7:517-520

Li XY, Huang FH, Murphy JB, Gbur JR. EE (1998) Polyethylene Glycol and Maltose Enhance Somatic Embryo Maturation in Loblolly Pine (Pinus taeda L.). In Vitro Cellular and Developmental Biology - Plant 34:22-26.

Litz RE, Conover RA (1982) In vitro somatic embryogenesis and plant regeneration from Carica papaya L. ovular callus. Plant Science Letters 26:153-158.

Litz RE (1986) Effect of osmotic stress on somatic embryogenesis in Carica suspension cultures. Journal of the American Society for Horticultural Science 111:969-972.

Lo Schiavo F, Pitto L, Giuliano G, Torti G, Nutironchi V, Marazziti D, Vergara R, Orselli S, Terzi M (1989) DNA methylation of embryogenic carrot cell cultures and its variations as caused by mutation, differentiation, hormones and hypomethylating drugs. Theoretical and Applied Genetics 77:325-331.

Malabadi RB, Kumar SV, Mulgund GS, Nataraja K (2011) Induction of somatic embryogenesis in Papaya (Carica papaya). Research in Biotechnology 2:40-55.

Martin AB, Cuadrado Y, Guerra H, Gallego P, Hita O, Martin L, Dorado A, Villalobos N (2000) Differences in the contents of total sugars, reducing sugars, starch and sucrose in embryogenic and non-embryogenic calli from Medicago arborea L. Plant Science 154:143-151.

Maruyama E, Hosoi Y (2007) Polyethylene glycol enhance somatic embryo production in Japanese cedar (Cryptomeria japonica D. Don). Propagation of Ornamental Plants 7:57-61.

Mishra M, Shukla N, Chandra R (2010) Role of polyethylene glycol in maturation and germination of trasformed somatic embryos of papaya (Carica papaya L.). Acta Horticulturae 851:227-230.

Morais PLD, Silva GG, Menezes JB, Maia FEN, Dantas DJ, Sales Junior R (2007) Postharvest shelf life of papaya UENF/CALIMAN 01 produced in Rio Grande do Norte. Revista Brasileira de Fruticultura 29:666-670.

Murashige T, Skoog F (1962) A revised medium for rapid growth and bioassays with tobacco tissue cultures. Physiologia Plantarum 15:473-497.
Pinto DLP, Almeida AMR, Rêgo MM, Silva ML, Oliveira EJ, Otoni WC (2011) Somatic embryogenesis from mature zygotic embryos of commercial passion fruit (Passiflora edulis Sims) genotypes. Plant Cell, Tissue and Organ Culture 3:521-530.

Santa-Catarina C, Silveira V, Balbuena TS, Viana AM, Estelita MEM, Handro W, Floh EIS (2006) IAA, ABA, polyamines and free amino acids associated with zygotic embryo development of Ocotea catharinensis. Plant Growth Regulation 49:237-247.

Schmildt ER, Amaral JAT, Schmildt O (2007) Sucrose on in vitro rooting phase of papaya tree 'Tainung 01'. Scientia Agraria 8:25-31.

Silva ML, Pinto DLP, Guerra MP, Floh EIS, Bruckner $\mathrm{CH}$, Otoni WC (2009) A novel regeneration system for a wild passion fruit species (Passiflora cincinnata Mast.) based on somatic embryogenesis from mature zygotic embryos. Plant Cell, Tissue and Organ Culture 99:47-54.

Smulders MJM, de Klerk GJ (2011) Epigenetics in plant tissue culture. Plant Growth Regulation 63:137-146.

Sokal RR, Rohlf FJ (1995) Biometry: the principles of statistics in biological research. Freeman, New York.

Stasolla C, Yeung EC (2003) Recent advances in conifer somatic embryogenesis: improving somatic embryo quality. Plant Cell, Tissue and Organ Culture 74:15-35.

Walker DR, Parrott WA (2001) Effect of polyethylene glycol and sugar alcohols on soybean somatic embryo germination and conversion. Plant Cell, Tissue Organ and Culture 64:55-62.

Welin BV, Olson A, Nylander M, Palva ET (1994) Characterisation and differential expression of DHN/LEA/RAB -like genes during cold-acclimation and drought stress in Arabidopsis thaliana. Plant Molecular Biology 26:131-144.

Wind J, Smeekens S, Hanson J (2010) Sucrose: metabolite and signaling molecule. Phytochemistry 71:1610-1614.

Vahdati $\mathrm{K}$, Bayat S, Ebrahimzadeh $\mathrm{H}$, Jariteh $\mathrm{M}$, Mirmasoumi M (2008) Effect of exogenous ABA on somatic embryo maturation and germination in Persian walnut (Juglans regia L.). Plant Cell, Tissue and Organ Culture 93:163-171.

Vooková B, Kormuták A (2002) Some features of somatic embryo maturation of Algerian fir. In Vitro Cellular and Developmental Biology-Plant 38:549-551. 